GENDER STUDIES 19(1)/2020

\title{
sciendo
}

\subsection{8/genst-2021-0006}

\section{MASCULINITY, PARODY AND PROPAGANDA IN THE “TRANSYLVANIANS" TRILOGY}

\author{
CLAUDIA IOANA DOROHOLSCHI \\ West University of Timișoara, Romania \\ claudia.doroholschi@e-uvt.ro
}

\begin{abstract}
The article focuses on the successful series of Red Westerns/Easterns produced in Romania in the late 1970s and early 1980s, known as the "Transylvanians" trilogy. The article will look at the films in the specific context of the period, one characterized by the increasingly idiosyncratic evolution of the Romanian communist regime and by growing economic difficulties, and will examine the way in which the films construct models of masculinity at the intersection between three different types of masculine models: those of the American Western (whether adopted or parodied), those of traditional Romania (such as the idealized, wise peasant), and masculine typologies derived from communist propaganda. I will argue that the films skillfully balance the tension between a critique of American models, in the face of which Romanian models emerge as superior, and legitimizing themselves as well as relying heavily in their entertainment value on the very models of the American Western they are supposed to subvert.
\end{abstract}

Keywords: hegemonic masculinity, Transylvanians trilogy, propaganda, Red Westerns, spaghetti westerns.

\section{Introduction: Romanian film in the 'Golden Epoch'}

In 1971, Nicolae Ceaușescu, the president of Communist Romania, held a speech famously known as the 'July Theses'. It had the unfortunate effect of shattering what had been a few years of relaxation of the Communist rule, in the years after 1964, and came as a blow to Romanian culture and society, marking the beginning of a process of re-Stalinization. Ceauşescu had famously been inspired by his visit to a number of Asian Communist countries, particularly North Korea and Mao's China, into proposing a stricter version of 


\section{GENDER STUDIES 19(1)/2020}

Communism (Tismăneanu et al., 2006, p. 109). He had already demonstrated a desire to break free from Russia, notably by refusing to participate in the invasion of Czechoslovakia during the 1968 Prague Spring, and had been hailed as a possible reformer both within the country and abroad. The reform, however, moved into a different direction than it was hoped. In the 70s and 80s, until the fall of the regime in 1989, Ceaușescu's desire to break free from Russian control proved to be anything but a reformist impulse. His rule became increasingly autarchic and dictatorial, and contacts with the outside world were gradually severed, amid a serious economic crisis that started after 1975 and deepened throughout the 1980s. The July Theses were the document that marked the beginning of this period of dictatorial control. They advocated a strengthening of the Party's role at all levels of life, a rigorously controlled presence of political indoctrination in educational institutions, and an active presence of party propaganda in culture: the role of art was to be "to serve the people, the fatherland, the socialist society." It was to speak to "the broad masses of the public, especially to workers and peasants." All forms of art and media were to step up "atheist propaganda" and "cultivate more the advanced figure of the worker, of the producer of material goods who is devoted body and soul to the cause of socialism and the advancement of the country." Simultaneously, "manifestations of cosmopolitism, the various artistic fashions borrowed from the capitalist world" were to be combated, and, as far as cinema was concerned, the circulation of the "detective, adventure films" was to be restricted, "banning films that cultivate violence and vulgarity, that propagate the bourgeois way of life" (Ceaușescu, 1971, available online; translation mine). Thus, the July Theses laid out the principles and operating rules of a propaganda machine which extended to all aspects of education and culture - including higher education, as well as the media, literature, and the cinema, a standard party rhetoric and a set of repressive mechanisms, whose main aim was to promote an exaltation of the country and of Ceaușescu himself as the leader (Tismăneanu et al., 2006, p. 109). Romania was gradually turning into a far more restrictive and dictatorial regime than most other countries of the Eastern European bloc, developing a type of communism characterized by maximum control and by an exacerbated personality cult of the President, who ruled the country for over 25 years, from 1965 until the fall of the communist regime in 1989.

Against this background of continuing repression, around the year 1980, Romania produced a trilogy of western films: The Prophet, the Gold and the Transylvanians (1977, directed by Dan Pița and written by Titus Popovici), The Actress, the Dollars and the Transylvanians (1979, directed by Mircea Veroiu and written by Titus Popovici, and The Oil, the Baby and the Transylvanians (1980, directed by Dan Piţa and written by Francisc 


\section{GENDER STUDIES 19(1)/2020}

Munteanu). The westerns, which were set in the States, but filmed entirely in Romania, in locations suggestive of the American West, were a success and remained popular in Romania (a 2012 statistic of the National Centre for Cinematography ranked them between 14 and 31 among the most watched Romanian films of all times; Consiliul Naţional al Cinematografiei, 2012). They recounted the adventures of three Transylvanian brothers, the Brads, around the 1880 s, and added extra layers of authenticity by rendering much of the dialogue in English (with varying degrees of success), and by creating sets that would look familiar to fans of the western genre (e.g. by borrowing from countries with more experience in making westerns, such as Czechoslovakia, the props that were not readily available in Romania).

This is a somewhat unlikely choice for a country where film-making was under strict control of the Party, and where much of the film production was propaganda, or at least partly so. According to Popescu (2011), out of the 550 films produced during the communist period, around 222 (40\%) "can be considered as being political, propagandistic in character" (p. 281, translation mine), but the rest of the films, aimed for entertainment, also had to comply with, if not actively promote, the Communist Party ideology. Film was seen as an essential instrument of party propaganda (Gheorghica, 2013, p. 7), and film production was highly regulated by the State. Films were sometimes made at the specific request of the Party or even under direct instructions from the president (Popescu, 2011, p. 224), and subject to rigorous scrutiny from the censorship. Films on contemporary topics had to provide examples of the communist new man, while Ceaușescu's increasingly nationalist turn meant an increase in the production of historical films which offered a highly distorted and heavily mythologized version of Romanian history, and placed Ceaușescu on a par with Romania's greatest rulers from the past (Popescu, 2011, p. 189), who were made to sound miraculously correct from an ideological point of view, as if they were all communists avant la lettre.

Film, however, remained highly popular. Like in Stalin's Russia, audiences went to the cinema, watched television, and the President himself was known to watch all latest productions of the national filmmakers. Filmmakers occasionally escaped into producing films that avoided ideological content (e.g. comedies, films for children) or emulated Western models (e.g. the "illegal communist" films that emulated highly popular Hollywood detective films; Popescu, 2011, pp. 194-195). Despite the July theses, foreign films still penetrated, although in small numbers, and heavily censored. Distributed were both films from the Communist bloc (Russian, Eastern European, Asian) and Western films, including American ones. The latter were shown under the pretext that they revealed the rottenness of the West, in consonance with the July theses (Gheorghica, 2013, p. 11; Popescu, 2011, pp. 180ff.). During 


\section{GENDER STUDIES 19(1)/2020}

the increasingly isolated $1980 \mathrm{~s}$, television programs had been reduced to as little as two hours per night on weekdays. Out of these, half were so-called news programs (in fact glorifying accounts of the grandiose deeds and speeches of the Dictator), followed by 'patriotic songs' and poems programs celebrating Ceaușescu as a redeemer and the current period as the 'Golden Epoch' in Romanian history. Even so, on Saturday evenings streets would be deserted because Romanians would be at home watching the hugely popular American soap Dallas. The series was apparently imported because Ceaușescu believed it accurately rendered the rottenness of the Western world (Gillespie \& Welch, 2008), but enjoyed by audiences on quite another level (reportedly the film's star Larry Hagman went as far as assuming that it had in fact contributed to the fall of the Romanian regime by showing Romanians what they could have but did not; Juddery, 2007). Romanian audiences were familiar with the classical John Ford westerns as well as the European takes on the genre, and the German series Winnetou, for instance, enjoyed great popularity. If Western - and particularly American - films were allowed through censorship under the pretext that they showed the decadence of the Western world, this was not how they were enjoyed by audiences, for whom American films and Hollywood represented the canon, and provided an ideal of America as the centre, possibly underscored by the authority of America as anticommunist.. Moreover, the Americans had been expected, as allies, to save Romania from the Communist take-over after World War II, and were still regarded as potential saviours, guardians of democracy and ideal land to which many Romanians would have escaped, if they only could. Thus, the America of popular imagination was radically different from the America of the official discourse, a land of capitalist decadence and moral debauchery, where capitalist monopoly rules (Fătu-Tutoveanu, 2010). The relation of the US with the Ceaușescu regime was equally ambivalent in the period. The US had hailed his anti-Russian position, and in 1975 had granted Romania the status of "most favored nation". By 1983, it was clear that the direction in which the regime was going was more sinister, as outlined in a report issued by the National Council for Soviet and East European Research, which gave an accurate image of Ceaușescu's increasingly dictatorial ways, but described him as a necessary evil since his elimination would have strengthened the position of Russia (Fischer, 1983, p. $\mathrm{v})$.

In what follows, I will look at the Transylvanians trilogy in an attempt to explore the way in which the films position themselves in relation to these political and ideological complexities, situated as they are at the intersection between entertainment and propaganda. They are particularly interesting as representations of America in communist Romania, 


\section{GENDER STUDIES 19(1)/2020}

enjoying great popularity with audiences, but also scoring high on propaganda background. The two directors, Dan Pița and Mircea Veroiu, were both experienced and prolific, known both for films with a strong propaganda component and films that had more artistic ambitions. The authors of the screenplays, Titus Popovici and Francisc Munteanu, were among the most prominent in Romanian pre-1989 cinema, and worked on many of the period's greatest propaganda and history productions (Popescu calls Titus Popovici "the master of artfully made propaganda scripts"; 2011, p. 199, my translation). In examining how the films balance propaganda and entertainment and how they make use of the genre of the western in the process, I will focus on how they construct models of masculinity, seen as the masculine ideal proposed to viewers by the highly censored film-makers. All propaganda needs role models, and in Communist propaganda the role of ideal masculinity was essential. For all its promotion of equality, Communism remained patriarchal, and relied on traditional gender roles. Like in Stalinist Russia (Clements et al., 2002, p. 194), Communist Romania saw the 'new man' mainly as a 'man'. The increase in female employment did not necessarily entail as much emancipation as communist propaganda claimed it did. Women were still expected to be mainly mothers and breeders. There was a ban on abortions, women were rewarded for having more than five children, and there were fines for couples that did not procreate. Female employment did increase in accord with Communist social and economic policies, but otherwise traditional gender relations in the Romanian society were preserved. While the propaganda models offered for females tended to combine images of females working traditional male jobs (such as operating tractors or cranes) while remaining feminine and motherly, men were expected to be physically strong and hard-working, and contribute, with complete dedication and impeccable ideological submission to the Party's directives, to building Communism in Romania. Films consistently offered such idealized role models as vehicles for propaganda. In analyzing how the Transylvanians trilogy addresses this idealized masculinity, I will use Connell's concept of hegemonic masculinity (Connell, 1987 and 2005), and I will attempt to look at the way in which the masculine model proposed by Communist propaganda interacts on the one hand with the American masculinity as projected by Party ideology, and on the other hand with masculinity as established in the western genre. 


\section{GENDER STUDIES 19(1)/2020}

\section{The Transylvanians trilogy, the Mămăligă-Western, and nationalist propaganda}

Sometimes lovingly called in the recent Romanian media 'Mămăligă-Westerns' (mămăligă, polenta, is to Romanian peasants what spaghetti are to Italians), the Transylvanians play on the humorous contrast between the familiar American Western setting and the Romanian characters, three brothers from the Transylvanian village of Poplaca, whose very name epitomizes remote rural Romania. The contrast between the two worlds (and between the English language and the rural Transylvanian accent of the three brothers) is often quite successfully played on for humorous effect. Situating themselves in what had by then become the tradition of European Westerns, from the German Winnetou films to Sergio Leone's Spaghetti Westerns (to whose Dollars Trilogy and The Good, The Bad and the Ugly the titles in the series seem to allude), and to the Bud Spencer/Terence Hill westerns which were popular in Romania at the time, the Transylvanians films counterbalance the American setting by an exacerbated nationalism in accord with propaganda requirements and with the increasingly patriotic rhetoric of the regime.

The first film of the series, The Prophet, the Dollars and the Transylvanians, introduces the trio of brothers who arrived in the American West some time around $1880-\mathrm{a}$ symmetric, allusive hundred years before contemporary Romania -, when Transylvania was still a part of the Austro-Hungarian Empire. This constituted a great opportunity on the one hand to create an escapist projection that held no immediate ideological pitfalls and was free from the thematic constraints that would have faced films set in contemporary Romania, and on the other hand to engage in patriotic propaganda, since the Romanian peasants in Transylvania, presented as a legitimate part of the Romanian people, are shown as being under the oppression of a foreign power. ${ }^{1}$ The middle brother, played by Ovidiu Iuliu Moldovan, is already in America, and has grown into a Clint Eastwood/Terence Hill/Franco Nero-type gunman, a rough morose unshaved loner who can draw his gun faster than everyone else. He is suitably named Ion, which goes as the most typical Romanian name, but holds an archaic and rural ring, and its metamorphosis into Johnny is inherently comical. The other two brothers, Traian and Romulus (Romi), have come to bring Johnny back to Transylvania. Traian, the eldest, acts as the patriarch who is in charge of the other two, and

\footnotetext{
${ }^{1}$ Although at the time Romania did not yet include Transylvania, the brothers refer to their country of origin as 'Romania' (implying that they are committed to the idea of national unity), while the eldest brother, Traian, confesses that he has escaped over the mountains to help his Romanian brothers fight against the Turks, and had to leave Transylvania because he was persecuted by the Austro-Hungarian authorities upon his return.
} 


\section{GENDER STUDIES 19(1)/2020}

stubbornly sticks to his rural Romanian ways - including his flamboyant sheepskin (of the kind that Romanian shepherds could be seen wearing well into the 1990s). Their names are equally suggestive of Romanian nationalist mythology, which idealized the Romanian people as the quasi-mystic union between the Roman conquerors of Dacia and the local Dacians. Suitably, the names of characters who are supposed to epitomize Romanianness are a combination of Roman and (supposedly) Dacian. Traian and Romulus are Roman names suggestive of the Latin origin of the Romanians in Transylvania (used to assert national identity there especially since the $18^{\text {th }}$ century) - and are both names of nation-founders: Romulus the founder of Rome and Trajan, the conqueror of Dacia and therefore literally the arch-patriarch, founder of the Romanian people according to the founding myth current in Romanian party propaganda. The brothers' family name, Brad, has the advantage of sounding American enough, while being at the same time a Romanian family name which means 'firtree'. It thus brings in connotations of the archaic link between people and nature, their native land - a frequent theme in nationalist propaganda - and may have been chosen because it was one of the words supposedly tracked down to the Dacian language substratum (e.g. Russu, 1967, p. 203). For extra comic effect, the patriarch Traian (who throughout most of the trilogy wears his trademark traditional Romanian shepherd's attire) is played by a heavily moustachioed Ilarion Ciobanu, a well-known Romanian actor whose last name translates as 'shepherd', and who moreover may have evoked to Romanian cinema buffs the archetypal figure of the Dacian, since he played the Dacian Gerula in the 1968 film Columna.

Most of The Prophet, the Gold and the Transylvanians, from plot to characterization, is equally consistent with party propaganda. The film is set in Utah, and features a set of characters painted in relentless black and white, with most of the Americans depicted as villains with no redeeming features. The film's greatest villain is a Mormon priest, Walthrope, seconded by a chorus of no less than 15 wives. He controls the whole town, placing a monopoly on the gold which he confiscates from Johnny and his fellow miners. His sadistic, methodical meanness is complemented by the less styled, more brutal meanness of his acolytes. In consonance with accredited propaganda imagery, America is under the absolute rule of the capital, of monopoly. Americans are driven by an insatiable thirst for money, which they pursue ruthlessly; they are violent, immoral and prone to over-indulgence in sex and alcohol. The Mormons are demonized, making use of religion as a mere rhetorical device 


\section{GENDER STUDIES 19(1)/2020}

used to cynically manipulate everyone else around ${ }^{2}$. In contrast, for all the comic clash between Traian and Romi's peasant ways and the more fashionable world in which they do not fit, the Romanians are the idealized perfect opposite of the Americans: principled, generous, firm but fair. Johnny himself, despite his adaptation to the American ways, has remained a Romanian at heart and delivers inspirational speeches to his brother-miners, urging them to rebel against their oppressor.

The Actress, the Dollars and the Transylvanians, the shortest film of the series (it lasts only a little over an hour) is also the most schematically plotted. It starts off with a train robbery undertaken by bandits posing as American Indians, and has Traian fall for a flimsy actress going by the very literary name of Anabelle Lee, whose acting he mistakes for genuine emotion. Once again, most Americans are bandits, with the exception of the Native Americans, who are being set up by the money-hungry villains - all people on the robbed train are murdered and scalped to make it seem as if the Natives are to blame. The actress herself - for whom Traian temporarily gives up his traditional attire and dresses like a gentleman - proves to be associated with the very same bandits, and only attempts to use Traian for her evil pursuits.

The third film of the series, The Oil, the Baby and the Transylvanians, is the most complex of the films, and arguably the most successful. If in the former two films Titus Popovici has Traian deliver at least one unlikely, anachronistic propaganda speech (e.g. on a lone walk with the actress, he tries to charm her by telling her that at present the Romanian people are oppressed, but one day they will rise and become empowered), the last film of the trilogy is free from such blatant and mechanical propaganda add-ons, although it is still ideologically correct in presenting the Romanians as superior to the Americans, and in making them stick to their relentless, trilogy-long wish to return to their native Poplaca, despite any amount of success they might encounter on the American soil (and underneath it, since the film has Traian unwittingly find oil while trying to dig a well in the barren soil of a newly-purchased American farm). However, this is the least ideological and most nuanced film of the trilogy, and merits a more detailed discussion, which I will undertake later in the paper.

The evolution of the characters throughout the series seems to be determined by the immediate needs of each individual stand-alone script, not by any coherent overarching

\footnotetext{
${ }^{2}$ This is a nod to Communist Party propaganda, which relentlessly denounced all types of religion, particularly less traditional religious movements such as Baptists or Pentecostals, which involved proselytism and were harder to control than the established Orthodox Church (Tismăneanu et al., 2006)
} 


\section{GENDER STUDIES 19(1)/2020}

concept. For example, what seems to have been an initial intention to enlarge the group of the Transylvanians by adding a new character in each film (Bob the ex-slave in the first film, and the son of a Native American chief in the second) is not carried over into the last film of the series, where the two characters no longer appear. The one cohesive plot element is the relationship of Romi and his young American wife June - she is found as an orphan in the first film, an idyll develops in the second, and the characters get married and have a baby by the end of the third.

The main plot device throughout the three films remains the relation between the Romanian characters and the American West, perhaps best summed up by their relation with the English language. Johnny masters English and speaks it fluently, despite his accent - just as he is fluent in gun-wielding and in the American way as a whole. Young Romi is charmed by America, and gradually learns the language - at first by trying to read words out in Romanian fashion from a dictionary he carries around, and wondering why people do not speak English the way it is written in the dictionary; then, gradually, as he gets married to the ethereal June and integrates further into the American way of life which he is rather fascinated by, he learns to speak and understand the language. The patriarch Traian, on the other hand, never bothers: throughout the trilogy, he insists on talking in Romanian to Americans as if they ought to understand him, and hangs on to the language the way he hangs on to his traditional costume and to his traditional liquor (he patriotically swears by the palinka of home over the American whiskey). It is also in Romanian that he tries to charm his actress, and also in Romanian that he delivers to her his patriotic speeches, of which she does not understand a word. In the last film of the series, however, he suddenly bursts out in perfect English in a moment of crisis, proving that it is not that he is not capable or willing to learn the language of the foreign land - he can master it, but he prefers his own.

\section{The quick pistol and the Plevna gun: masculinity and sexuality in the Transylvanians}

The main vehicle of propaganda in the Transylvanians trilogy is the interplay between its various masculine models: that of the rough, tough Western hero and the Western villain; the American man as projected by communist ideology; the Romanian socialist 'new man', and the Romanian peasant, idealized by Romanian nationalist propaganda. In analysing these, I will use the concept of hegemonic masculinity as defined by Connell, as the "social ascendancy achieved in a play of social forces that extends beyond contests of brute power 


\section{GENDER STUDIES 19(1)/2020}

into the organization of private life and cultural processes." (Connell, 1987, p. 184), not merely masculine domination established by force, but the masculine hierarchy as embedded in the social structure. As Connell shows, "the winning of hegemony often involves the creation of models of masculinity which are quite specifically fantasy figures, such as the film characters played by Humphrey Bogart, John Wayne and Sylvester Stallone," and the media are often the vehicle by which these models are conveyed to audiences (Connell, 1987, p. 184). In their interaction with hegemonic masculinity, the other types of masculinity situate themselves in a relation of subordination (are oppressed), become complicit (in the case of men who do not fit the hegemonic masculine model, but affiliate themselves to it and benefit from its authority), or are marginalized (Connell, 2005, pp. 78-81). According to Connell $(1987,2005)$, the primary function of this masculinity is the subordination of women and the establishing of the patriarchal order in a particular cultural and social environment. In the context of party propaganda, however, the ascendancy of these masculine ideal models subordinates the idea of gender dominance to the idea of political dominance, and they serve primarily ideological functions, as they are meant to show how adherence to correct Party ideology places men in a position of social superiority - not only over women, but over all potential alternative masculine ideals. Although this displaces the term a little from the framework in which it is used by Connell, I believe it is nonetheless useful in describing the way in which the films propose the revision of social hierarchies and the substitution of one set of models (capitalist, Western, those of the western) with another (Romanian, rural, archaic, nationalist), as well as the tensions inherent in the approach.

The American Western film has long been a site of reinforcement of "traditional masculinity: individual skills, wit, disposition to command, and self-control of both emotions and body" - qualities necessary for the "monumental masculinity" of the cowboy to survive the harshness of the American Frontier (Bordin, 2014, pp. 30-31). Mitchell (1996) points out that in film the genre of the Western emerged at the same time as the second feminist movement and regained popularity in the 1950s and 60s, another moment he identifies as one in which women increasingly became more independent, and men needed to reinvent and reinforce the notion of "how to be a man" (p. 153). The same happens in Italy in the case of spaghetti westerns, which emerged during the 1960s, "a period of increasingly militant Italian feminism, a factor difficult not to relate to the sidelining of femininity by the spaghetti western" (Günsberg, 2005, pp. 181-182). This might have been a factor in the success of the Communist westerns, which, as elsewhere, reassert hegemonic masculinity in a time when 


\section{GENDER STUDIES 19(1)/2020}

masculine role was challenged, at least superficially and partially, by Communist propaganda and the more active political and economic role of women.

Thus, like American westerns, the Transylvanians trilogy revolves around mainly male figures, while females are also frequently "constructed according to the traditional patriarchal madonna-whore divide" (Günsberg, 2005, p. 186) of the traditional western. At the same time, the films consistently confirm the superiority of the three Romanian heroes two of whom would easily qualify as superheroes - to pretty much everyone else, and primarily to the established American order, which, in the films' ideological take, is one in which authority is held by sometimes sexually perverted, always capital-driven and immoral men. Occasional representatives of the state (military men or sheriffs) are flawed and prove to be powerless in front of the demonized hegemony of the bandits. The Transylvanian trio successfully challenges the American order by proposing alternative masculine models, and their superiority is quickly recognized by all redeemable American figures (those who do not accept it get arrested or shot, without exception, by the end of the films). The first and arguably most important of these is Traian, the patriarch par excellence. Older than his brothers and with no family of his own, of bear-like size and strength and resounding voice, he takes on the role of father-figure for his younger brothers, as well as for a few other characters he meets en route. He is presented as strong, macho, a pacifist at heart (he is constantly trying to make Johnny give up his guns), but able to lead and win any fight when needed. If he makes an error, as in falling for the actress in the second film of the series, this is the result of his faith in human nature and ingrained honesty - or is compensated by luck: he wins at poker despite the fact that he plays his cards wrong, his dice roll as if they had magic powers, and he strikes oil as he tries to dig a well (because he has argued with his Hungarian neighbour who used to provide him with water). He proudly displays a rural, archaic type of masculinity which seems blatantly (and humorously) out of place in the Western décor, but which systematically wins over everyone else's existential project. One could speculate that the mechanisms at play here are a reversal of the Romanian inferiority complex towards the American model, going beyond Communist propaganda into a gratification of the nationalist instinct: at first, the Poplaca peasant seems inept, primitive and unable to cope with the 'civilised' world, but he eventually proves superior in terms of moral principles, wit, as well as physical prowess, a demonstration of how 'ours' are better than 'theirs.'

The other candidate for the superhero role is Johnny, whose unflinching solidity, quickness, and seductive melancholy seem designed to beat Western heroes at their own 


\section{GENDER STUDIES 19(1)/2020}

weapons. As mentioned earlier, he emulates a long series of Spaghetti Western characters but with a hint of the national hero, since he recalls the image of the haiduc, a sort of Romanian desperado-cum-Robin Hood mythologized by Communist propaganda as one who steals from the oppressors/from the rich and gives to the poor. In the first film, he is the one who delivers an inspirational speech to his fellow-miners, trying to persuade them to rise against their oppressor, the Mormon priest; in the third, he is a bounty hunter, but one whose need for money is doubled by dedication for the hygiene of society.

By comparison, the youngest brother Romulus acts as the group's fool, offering comic relief. He is young and innocent but intelligent and possibly a little bookish and artistic, if we are to judge by his dictionary and by the pipe on which he plays traditional Romanian folk music in the first of the films. He recalls another Romanian folk character, the witty fool Păcală, resuscitated in the 1950s as an example of rural wisdom that, under the guise of foolishness, taxes unfairness and stupidity (notably in the hugely popular 1974 film by Geo Saizescu). Romi's innocence makes him 'dangerously' prone to American influence, and he offers a counterpoint of 'modernization' to Traian's traditional masculinity. As the youngest brother and the one with the least masculine body frame (he is the shortest of the brothers, and not particularly masculine in appearance), he lives in the shade of his brothers' dominating masculinity. However, his sensitivity allows him to enact a dimension of masculinity the other two brothers, rugged loners, do not: as we witness his maturation throughout the series, despite the fact that both Traian and Johnny have brief platonic romances, Romi is the only one of the protagonists who fulfils romance by marriage and an (obviously male) child.

Despite their professed pacifism, all three brothers consistently demonstrate their ability to dominate by sheer masculine strength, which helps them establish and confirm a leading position in relation to other men. Traian is a great gunman: he suitably owns the biggest rifle of them all, one he has confiscated from the Turks at Plevna ${ }^{3}$ and which shoots down everything in sight like a cannon, but he is also capable of killing with his bare hands, which is how he disposes of the main villain in the second film. Johnny literally beats Americans at their own weapons, since he is a master of the quick pistol - while young Romi is just learning to fire his gun but does so rather effectively to defend his newly acquired love June.

The films' sexuality is entirely dissimulated in such ways. Otherwise, the films' take on sexual prowess is entirely framed by conventional notions of marriage and soviet new

\footnotetext{
${ }^{3}$ Major battle during the Romanian War of Independence against the Ottoman Empire (as part of the RussoTurkish war, 1877-1878).
} 


\section{GENDER STUDIES 19(1)/2020}

man-style self-discipline. Traian and Johnny are unmarried, for unexplained reasons, but one can easily speculate that, like in the case of war film heroes (Donald, in Beynon 2002, p. 67), the presence of a woman would diminish some of their independent, powerful masculinity. Sexuality is meant for family and procreation, and is only a positive force within the confines of the disciplined framework of the family. Anything else is presented as typical American debauchery, particularly embodied by the flirtatious actress, and especially by the Mormon priest, who is sexually insatiable. Not only is he the proud owner of 15 wives, but we are given a glimpse into the perverse mechanics of this setup, as we see him wake up next to one of his wives (whom he calls "Mrs. Walthrope"), and, as he declares himself satisfied with her services, ask her which of the wives he requires the following night. This is done methodically, by consulting a black book that could well be his Bible. His aides proceed to rape women, suggesting that in the film's ideological framework religion, power and uncontrolled sexual urges go hand in hand (for a discussion of this use of eroticism in Romanian propaganda to "disclose the shortcomings of the decaying Western society", see Turcuș, 2014, p. 63).

More disturbingly perhaps, the authority of the three brothers is established on a gender and racial level as well, highlighting the ambivalence inherent in the communist egalitarian rhetoric. While they are all perfect gentlemen towards women, they inhabit an unquestionably unchallenged masculine world. The few redeemable women are - like June usually helpless, blonde, and innocent. In contrast with her, in the first two films of the trilogy most women - because they are women and/or because they are American - are presented as manipulative and sex-obsessed (the actress), or as impossible harridans and helpless victims (the prophets' wives and sister). While the actress is set right by being arrested, in The Prophet, the Gold and the Transylvanians women are put in their place by physical violence. Most notably, Traian and Romi, captured by the Mormon and subject to forced labour under the supervision of his evil oldest wife, rebel by pulling down her trousers and beating her, in an assertion of macho power presented as slapstick comedy. However, to do justice to the films' rendering of gender relations, it must be noted that in the person of the Mormon's senior wife the brothers punish at the same time the woman, the capitalist oppressor, the slave driver, the Mormon, and the American, with the gender dimension possibly carrying least weight.

Significantly, the authority of the Transylvanian brothers is also asserted over other races. Perhaps as an extra attempt at authenticity, the films feature a black character, Bob (in the two films of the series) and American Indians (only in The Actress, the Dollars and the 


\section{GENDER STUDIES 19(1)/2020}

Transylvanians). Both are presented as marginalized and victimized in the existing American order: Bob is the servant-slave of a Confederate officer who refuses to believe the war (and slavery) is over, while the Native Americans are blamed for robbing a train which is in fact robbed by the American bandits, and the tribe's chief is shot when he comes to town to explain the truth. The egalitarian communist rhetoric requires the Transylvanians to be the allies of these oppressed races, and indeed they are rescued by them, but they are not in fact given a voice. Instead, they function as a sort of vehicles for validating the authority of the protagonists. In The Prophet, the Gold and the Transylvanians, Bob is won at poker by Traian, who is shocked that this can happen ("How can you win a man at cards, he's not a ram?"), and promptly tells Bob that he is a free man, but Bob insists on acting as if Traian is his master, and chooses to follow him, taking on a subservient role. In the next film, he is following the brothers and has learned a little Romanian, which he speaks with a comically incongruous Transylvanian accent. In The Artist, the Dollars and the Transylvanians, the Native American son of the shot tribe chief is a sort of quiet noble savage who is helped by the Transylvanians set things right for his tribe, and then also decides to follow them. He is inarticulate and somewhat helpless, but makes use of his exceptional physique to climb up and down roofs and poles a lot, displaying his muscular naked torso in the process. Traian calls him a Turk (because of the colour of his skin, but also because it is the otherness he is used to from his Plevna war), and, in a highly politically incorrect punch line to the film, he tells the others: "Look, our Turk's also coming with us. If things keep going like this, by the time we get to Poplaca we'll be like Noah's Ark."

\section{The Oil, the Baby and the Transylvanians: Contesting masculinities}

The observations above apply only partially to the third film of the series. The most nuanced film of the trilogy, it has a more complex plot and attempts to give a more threedimensional view of the characters. The result is that the hegemony of Traian's archaic patriarchal model is systematically challenged in a way that does not occur in the previous two films, thus suggesting a possible questioning of this patriarchal type of authority. More weight is given to Johnny, who is the true hero of the film, and gets promoted from bounty hunter to deputy sheriff. Traian, in contrast, is increasingly stubborn in his traditional ways, and increasingly ridiculous in the process. His patriotic tendencies have become exaggerated and turned into downright nationalist stubbornness, as displayed in his relationship with the Hungarian Transylvanian who owns the neighbouring farm, a relationship which transitions 


\section{GENDER STUDIES 19(1)/2020}

from lyrical drunken effusions of nostalgia for a shared homeland to radical outbursts of nationalist pride inspired by allegiance to one's own national mythology and history (they have a feud over their respective national heroes, Avram Iancu and Kossuth Lajos).

Romi himself challenges Traian's authority; if in the first two films he is reduced to grumbling against his elder brother, here he stages a few acts of rebellion: first, by impregnating June out of wedlock (triggering a quick move to marriage to set things right), then by purchasing a farm without his brother's authorization and against his will, a purchase that Traian reprimands him for (the farm is derelict, and the land is barren), but which he turns into a home for them and for his pregnant soon-to-be wife. The farm felicitously turns out to be sitting on a reservoir of oil, eventually proving the fool Romi to be right, and the self-righteous Traian to be the fool - but turning both of them into the lucky winners of the jackpot at the very end.

Johnny also acquires a more human face, and a degree of ambiguity. He is a bounty hunter, in it for the money - he does need it for his brothers and for their return to Poplaca (As Corciovescu notes, returning home was an ideologically required atonement for any pre1989 films depicting migration), but it gives him the opportunity to act even more the cool, cynical Spaghetti Western hero. He almost embarks on an idyll with one of the beautiful daughters of the Hungarian farmer, who asks him to "make this country [his] own", and he almost hesitates considering that he could perhaps become an American. The film, incidentally, also pays more attention to the female characters. For the first time, June has opinions, not to mention that the Hungarian lady has the initiative in her relation with Johnny.

Nevertheless, in the end it is still the old patriarch who restores the equilibrium. Before the final credits kick in, Romi and June are married (by Traian's direct intervention, since he is the one who sets them straight and even manages to find them an Orthodox priest), the villains are defeated jointly by the Romanians and the Hungarians, with the serious contribution of Traian's Plevna gun, and everyone, now rich because Traian has struck oil, is headed back to mythical Poplaca. However, this equilibrium is one that is much more fraught with uncertainty than in the previous two films, has been much more genuinely challenged, and is to a great extent the result of luck, rather than sustained ideological correctness. There are no political speeches this time, and there seems to be a more subtle take on nationalism/patriotism: the three characters still want to return home because they remain, first and foremost, Romanian, but Traian's exacerbated nationalism, which in the first two films was unflinchingly validated, is critiqued here by the fact that he is made to act irrationally towards his Hungarian neighbour. Moreover, the American way is no longer as 


\section{GENDER STUDIES 19(1)/2020}

deeply negated as in the first two films: America is still the land of the ruthless pursuit of the capital and of the saloon as a place of perdition, but it is also the place where you can set up your own farm and strike oil in the process, where you can, in other words, partake in the American Dream. The return of the characters to their homeland certainly validates their patriotic choice; however, the film does not invalidate the Hungarians' choice to stay and become Americans, a choice which the previous two films would have vilified.

It is hard to establish whether this questioning is due to the screenwriter's choices (this is the only film written by Francisc Munteanu, who may have had a different view of how films should please censors than Titus Popovici did in the first two); whether the success of the first two films led the filmmakers to believe that they could now allow themselves more artistic freedom; or whether this is the result of the mini-thaw Cristian Tudor Popescu speaks of in his discussion of Romanian propaganda films, a mini-thaw that began around 1980, when a group of directors pleaded with the Communist Party apparatus to allow them more artistic freedom, and which ended in 1983 with the 'Mangalia theses,' a repeat of the July theses issued by Ceaușescu who was worried Romanian cinema was going astray (Popescu, 2011, pp. 235-239). ${ }^{4}$ What is certain is that this was the last film of the trilogy, and marked the end of the Romanian experimentation with the Western genre.

\section{Conclusions: between Romanian political propaganda and American entertainment}

The complexities in The Oil, The Baby and the Transylvanians highlight what is in fact the ambivalence of the whole series, and of its characteristic mixture of western, parody and propaganda. For all their ideological content, the films remain rather charming. Despite the occasional patriotic speech, and with the help of Ilarion Ciobanu's excellent, very natural acting, Traian seduces as a believable Romanian peasant, and the humorous contrast between him and the rest of the American world often generates good quality comedy. Ovidiu Iuliu Moldovan is also rather successful as a western hero. Although systematically challenged by Traian, he remains admirable, and admirable as a western gunman, never truly ideologically castigated for adhering to the American ways, and thus undermining the very challenge the films originally intended. The cold-blooded, self-controlled, quick-witted western hero (Johnny) and the grounded, wise, solid Romanian peasant (Traian), the quick pistol and the

\footnotetext{
${ }^{4}$ Coincidentally, the Mangalia theses were inspired by Ceaușescu's watching Faleze de nisip (Popescu, 2011), also directed by Dan Pița, the director of the first and the last film of the Transylvanians series.
} 


\section{GENDER STUDIES 19(1)/2020}

Plevna gun, have allied in their reinforcement of hegemonic masculinity and national identity. Ultimately, audiences are delighted by both models, and by the interplay between them. Nor does the genre of the western itself truly end up as being parodied or challenged. The endings are resolved western style, by massive choreographed gunfights, in which we get gratification out of the fact that the good men win. Ultimately, the films rely on exploiting the western formula of attracting the audience, not that of the communist propaganda film, and the films remain Romanian westerns before they are political propaganda. The American West may be ideologically condemned, but it is faithfully imitated, in a filmic formula which was successful throughout the Soviet bloc.

Whether the authors of the films were conscious or not of the double pull of their films is hard to establish, but they may well have been. As early as the first years of the Stalin regime, the role of cinema was heavily debated, and oscillated between a tool for ideological education and a means to provide entertainment to the masses (Dumančić, 2010, pp. 45-46). In the 1970s and 1980s, Romanian films attempted to do both, and sometimes emulated established Hollywood formulas to enhance the mass appeal of films which had to remain ideologically correct. At the same time, by the 1980s double speak had become rather usual in Romanian literature, theatre or films. It had become habitual to slip subversive content through hiding it beneath politically correct rhetoric which would have fooled censorship, and it was habitual for such works to function as overlapping parallel texts, one addressed to the Party censors and one addressed to the wider audiences. It is likely that all three films were trying to find a formula that would ensure the film success with both the critics and the masses, and it was rather usual to do so in two different, parallel ways. As Trocan (2015) notes, like Westerns elsewhere, the films reflect their audiences' moral codes, but these moral codes lose centre stage in entertainment-focused scenes such as shoot-outs. The result was a hybrid that embedded in its structure two contradictory masculine role models, and thus offered audiences two different sets of fantasies - the nationalist fantasy Communists had enlisted for propaganda purposes, and the fantasy of the Romanian as a hero of the western, whose popularity had long transcended the boundaries of the American myth and had become a global one, and in which America holds a position of centrality in the imagination of the public. Despite what communist propaganda would have required, there are no winners or losers in this game whose stake is establishing hegemony: the films do legitimize Romanians over Americans, but it is not entirely clear which model has cannibalized which. Ultimately, what the films do is offer Romanians, marginalized by the isolationist politics of Ceaușescu as 


\section{GENDER STUDIES 19(1)/2020}

well as by a history that placed them outside the world's political and economic mainstream, a fantasy of centrality.

\section{References}

Beynon, J. (2002). Masculinities and culture. Philadelphia: Open University.

Bordin, E. (2014). Masculinity \& Westerns: Regenerations at the turn of the millennium. Verona: Ombre Corte.

Ceaușescu, N. (1971). Propuneri de măsuri pentru îmbunătățirea activității politico-ideologice, de educare marxist-leninistă a membrilor de partid, a tuturor oamenilor muncii. Retrieved from https:// ro.wikisource.org/wiki/Tezele_din_iulie [Accessed 2015, July 29].

Clements, B. E., Friedman, R., \& Healey, D. (2002). Russian masculinities in history and culture. Houndmills: Palgrave.

Connell, R. (1987). Gender and power: society, the person, and sexual politics. Stanford: Stanford University Press.

Connell, R. (2005). Masculinities. Berkeley: University of California Press.

Consiliul Naţional al Cinematografiei. (2012). Film românesc total spectatori. Retrieved from http:// cnc.gov.ro/ wp-content/uploads/2013/08/film-romanesc-total-spectatori-20121.xls

[Accessed 2015, August 1].

Corciovescu, C. (2011). 'Pruncul, petrolul şi ardelenii' - cronică de film. Retrieved from http://aarc.ro/en/ articol/pruncul-petrolul-si-ardelenii [Accessed 2020, November 28].

Dumančić, M. (2010). Rescripting Stalinist masculinity: Contesting the male ideal in Soviet film and society, 1953-1968. A dissertation submitted to the faculty of the University of North Carolina at Chapel Hill in partial fulfillment of the requirements for the degree of Doctor of Philosophy in the Department of History. Retrieved from https://cdr.lib.unc.edu/indexablecontent/uuid:9080556a-0584-4a42-9b6fa85680bad596 [Accessed 2015, July 30].

Fătu-Tutoveanu, A. (2010). Identity stereotypes: the US in the Romanian media of the late 1940s - Political cartoons. Americana. E-journal of American Studies in Hungary. 6(2). Retrieved from: https:// americanaejournal.hu/vol6no2/fatu-tutoveanu [Accessed 2015, July 30].

Fischer, M. E. (1983). Nicolae Ceauşescu and the Romanian political leadership: Nationalization and personalization of power. Final Report to National Council for Soviet and East European Research. Retrieved from https://www.ucis.pitt.edu/nceeer/1983-626-10-Fischer.pdf [Accessed 2015, July 15].

Gheorghica, N. (2013). Romanian cinematography and filmcCulture during the communist regime. Euxeinos, 11 Retrieved from http://www.gce.unisg.ch/ /media/internet/content/dateien/instituteundcenters/gce/ euxeinos/nela\%20gherghica\%20euxeinos\%2011_2013.pdf [Accessed 2015, July 15].

Gillespie, N., \& Welch, M. (2008, April 7). How 'Dallas' won the Cold War. The Washington Post. Retrieved from http://www.washingtonpost.com/wp-dyn/content/article/2008/04/25/AR200804250 3103.html [Accessed 2015, August 3].

Günsberg, M. (2005). Italian cinema: Gender and genre. Houndmills, Basingstoke: Palgrave Macmillan.

Juddery, M. (2007, December 17). TV shows that changed the world. CNN. Retrieved from http:// edition.cnn.com/2007/LIVING/wayoflife/12/09/mf.tvshow.change.world/ [Accessed 2015, August 1].

Mitchell, L. C. (1996). Westerns: Making the man in fiction and film. Chicago: University of Chicago Press. 


\section{GENDER STUDIES 19(1)/2020}

Pița, D. (Director). (1977). Profetul, aurul şi ardelenii [Motion picture]. Bucureşti: Centrul national al cinematografiei, Casa de filme Trei.

Pița, D. (Director). (1980). Pruncul, petrolul și ardelenii [Motion picture]. Bucureşti: Centrul national al cinematografiei, Casa de filme Trei.

Popescu, C. T. (2011). Filmul surd în România mută: politică şi propagandă în filmul românesc de ficţiune (1912-1989). Iași: Polirom.

Russu, I. I. (1967). Limba traco-dacilor. București: Editura Științifică.

Tismăneanu, V. et al. (2006). Comisia prezidenţială pentru analiza dictaturii comuniste din românia. Raport final. Retrieved from http://www.presidency.ro/static/ordine/RAPORT_FINAL_CPA DCR.pdf [Accessed 2015, July 29].

Trocan, I. (2015). Western-ul românesc în trilogia Ardelenii. Istoria filmului românesc, December 6, 2015.

Retrieved from https://istoriafilmului.ro/articol/western-ul-romanesc-in-trilogia-ardelenii/ [Accessed 2020, November 30].

Turcuş, C. (2014). On socialist eroticism. Building and subverting propaganda in Romanian cinema before 1989. Ekphrasis. Images, Cinema, Theory, Media, 12(2), 60- 69.

Veroiu, M. (Director). (1979). Artista, dolarii și ardelenii [Motion picture]. Bucureşti: Centrul national al cinematografiei, Casa de filme Trei.

Claudia Ioana DOROHOLSCHI, $\mathrm{PhD}$, is a lecturer at the Department of Modern Languages and Literatures at the West University of Timisoara, Romania, where she teaches English and American literature, creative writing and academic writing. She has published articles in the fields of literature, with a special focus on the analysis of narrative, and on film studies. In the past few years, her research has mainly concentrated on academic writing, and she is a co-editor of University Writing in Central and Eastern Europe: Tradition, Transition, and Innovation, published by Springer in 2018. 